\title{
Prevenční povinnost při poskytování zdravotních a sociálních služeb
}

\section{Breach of Duty of Care by Providing Social and Health Care}

\author{
Ondřej Pavelek ${ }^{*}$
}

\begin{abstract}
Abstrakt
Cillem toho př̌spèvku je analýza občanskoprávni odpovédnosti prì poskytováni zdravotních a sociálních slǔ̌eb. Pozornost je vènována problematice protiprávnosti - və̌tahu generálni prevenčni povinnosti a povinnostem stanoveným konkerétnimi právnimi predpisy: zákonem č. 108/2006 Sb., o sociálnich službách a zákonem č.372/2011 Sb., o zdravotnich službách. Na dvou prǐpadech jsou analyzovány rovněž povin-

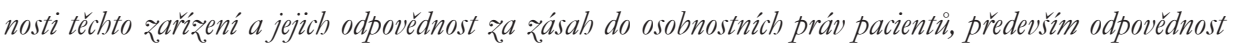
za üjmu na zdravi a prí usmrcení.
\end{abstract}

\section{Klíčová slova}

Odpovédnost; nábrada nemajetkové újmy; zdravotní slǔ̌by; sociálni služby; porušeni prevenčni povinnosti; práva pacientui; povinnosti zdravotního personálu.

\begin{abstract}
The aim of this contribution is to analyse the impact of civil liability of the providers of health and social services according to the Caech civil code (89/2012 Coll.). The focus lays on the unlawfulness - on the relationship between general prevention duty and duties stated by the special statutes; statute of social providers 108/2006 Coll. and statute of health care 372/2011 Coll. There are two special cases on which will be demonstrated the unlawfulness and breach of personal rights of individuals.
\end{abstract}

\section{Keywords}

Liability; Compensation of Non-pecuniary Loss; Health Care; Social Care; Breach of General Prevention Duty; Patient's Rights; Duties of Health Staff.

\section{1 Úvod}

Ačkoli je úprava poskytování zdravotních a sociálních služeb regulována převážně normami veřejného práva ${ }^{1}$, nelze pominout soukromoprávní aspekty zejména občanskoprávní odpovědnost. Vztah lékaře, resp. nemocnice nebo zařízení poskytujících sociální služby byl dlouhou dobu vnímán jako ryze veřejnoprávní. Tato situace se však postupně měnila a nyní lze přisvědčit tomu, že jde primárně o vztah soukromoprávní, nikoli veřjnoprávní. Z toho důvodu je nezbytné takto vnímat i odpovědnost těchto zařízení.

\footnotetext{
* Mgr. Bc. Ondřej Pavelek, doktorand, Katedra občanského práva, Právnická fakulta Masarykovy univerzity, Brno / Ph.D. student, Department of Civil Law, Faculty of Law, Masaryk University, Brno, Czech Republic / E-mail: ondrej.pavelek@law.muni.cz

1 Zákon č. 372/2011 Sb., o zdravotních službách; zákon č. 108/2006 Sb., o sociálních službách.
} 
Změny soukromého práva po 1. 1. 2014 se přirozeně dotkly významné oblasti - závazků z deliktů, včetně nové koncepce náhrady újmy. Vzhledem k povaze poskytování zdravotních a sociálních služeb dochází $\mathrm{k}$ (zaviněným i nezaviněným) zásahům do osobnostních práv člověka, kterému jsou tyto služby poskytovány, a proto by úprava odpovědnosti v obč. zák. neměla zůstat stranou pozornosti poskytovatelů těchto služeb.

Cílem př́spěvku je analýza protiprávnosti a vzájemného vztahu mezi protiprávností a tzv. generální prevenční povinností zakotvenou v S 2900 obč. zák.

\section{Občanskoprávní odpovědnost}

Nový občanský zákoník (dále jen obč. zák.) upravuje odpovědnost a náhradu újmy v Hlavě III, která je nazvána jako závazky z deliktů. Oproti původní úpravě v zákoně č. 40/1964, občanský zákoník (dále jen OZ 1964) rozlišuje zákonodárce škodu, tj. újmu majetkovou, a nemajetkovou újmu, které se hradí pouze v př́padech, kdy na ni odkáže zákon, jako např. v př́padě nemajetkové újmy na zdraví, nebo kdy byla výslovně ujednána. ${ }^{2} \mathrm{~V}$ praxi často uplatňovaným typem odpovědnosti podle OZ 1964 byla tzv. odpovědnost za škodu způsobenou okolnostmi, které mají původ v povaze použitého př́stroje podle \421a OZ 1964; šlo zejména o prípady zavádění katetru a následné perforace, např. poškození míchy. ${ }^{3}$ Původní úprava $\int 421$ a OZ 1964 byla kritizována a přezdívána jako „kladivo na nemocnice “4, a proto v \ 2936 obč. zák. byla př́ijata nová koncepce, která omezuje odpovědnost jen na prrípady, kdy škodu způsobila vada věci použité př́i plnění. Dalším případem, kdy mohou být odpovědná zdravotnická (sociálnî) zařízení je odpovědnost za škodu na odložených věcech ve smyslu \2945 obč. zák. nebo odpovědnost za škodu zpo̊sobenou těmi, kteří nemohou posoudit následky svého jednání. Jde především o dohled nad pacienty, kteří jsou nezletilí anebo o pacienty stižené duševní poruchou podle \2920 obč. zák. V praxi nejčastěji uplatňovaným typem odpovědnosti je obecná odpovědnost za újmu, která vznikne porušením zákona podle \2910 obč. zák.; jde zejména o odpovědnost za postup non lege artis a zásah do osobnosti člověka. ${ }^{5}$ Kromě tohoto může jít také o porušení obecné prevenční povinnosti, ${ }^{6}$ nyní zakotvené v \ 2900 obč. zák. Ustanovení \ 2957 obč. zák. pak upravuje způsob náhrady. Speciální ustanovení \ 2958 obč. zák. pak upravuje náhradu újmy na zdraví, tj. bolestné, náhradu za ztížení společenského uplatnění a tzv. další nemajetkové újmy; \2959 obč. zák.

2 \ 2894 odst. 2 obč. zák.

3 K tomu např. rozsudek Nejvyššího soudu ze dne 25. ř́jna 2006, sp. zn. 25 Cdo 1129/2005.

4 PETROV, Jan. Kladivo na zdravotnictví. [online] 10. 10. 2011 [cit. 15. 2. 2016]. Dostupné z: http://jinepravo.blogspot.cz/2011/10/kladivo-na-zdravotnictvi-421a-obc-zak_10.html

5 K tomu např. rozsudek Nejvyššího soudu ze dne 31. ř́jna 2013, sp. zn. 25 Cdo 1952/2012.

6 ŠKÁROVÁ, Marta. Odpovédnost za škodu na zdravípacienta zpisobená lékařem či zdravotnickým zař́zením [online] 29. 11. 2007 [cit. 15. 2. 2016]. Dostupné z: http://www.medicinskepravo.cz/2007/11/odpovednost-za-skodu-na-zdravi-pacienta.html 
upravuje náhradu tzv. sekundárních obětí při usmrcení nebo zvlášt' závažném ublížení na zdraví osoby blízké?

Důležité je z tohoto pohledu ustanovení \ 2971 obč. zák.: Odi̊vodňuji-li to zuláštni okolnosti,

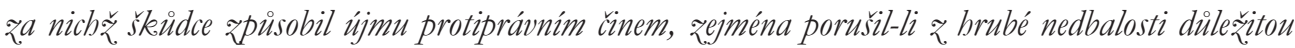
právni povinnost, anebo zpuisobil-li üjmu úmyslně z touby ničit, ubližit nebo z jiné pohnutky zvlást' zavrženihodné, nahradí škidce též nemajetkovou újmu každému, kdo zprisobenou újmu dìvodněpocit’uje jako osobni neštěstí, které nelze jinak odčinit. Lze s ohledem na toto ustanovení připustit, aby např. dítě žádalo náhradu nemajetkové újmy za to, že došlo k zásahu do osobnosti jeho matky, konkrétně tím, že např. byla delší dobu přikurtována, a žádat tak o náhradu nemajetkové újmy za zásah do prrirozeného práva - práva na rodinný život? Takové pojetí by poté vedlo k rozšiřování osob oprávněných k náhradě a je otázkou, zda by takový výklad byl v praxi udržitelný.

\section{Dva př́pady z praxe}

a) Pacientka byla hospitalizována na psychiatrickém oddělení s diagnózou delirium tremens, kde podléhala zvýšenému dohledu s možností omezení na lưžku. Pacientka byla večer agresivní, a proto byla pracovníky nemocnice omezena v kurtech. Cigarety a zapalovač jí byl pro nedodržování zákazu kouření odebrán a vložen do nočního stolku vedle postele. Pacientka si však uvolnila ruku z kurtů, podala si cigaretu a zapálila si ji; následně jí však zapálená cigareta spadla a postel začala hořet a způsobila si rozsáhlé popáleniny. ${ }^{8}$ Následně žalovala nemocnici o náhradu za bolest a ztížení společenského uplatnění podle \2958 obč. zák., protože nemocnice, resp. pracovníci, nad ní řádně nevykonávali dohled.

b) Ve druhém případě byla pacientka umístěna do domova se zvláštním režimem podle $\int 50$ odst. 1 zákona o sociálních službách pro osoby. Pacientka trpěla Alzheimerovou chorobou, byla nesoběstačná a dezorientovaná. $V$ nestř̌eženém okamžiku si otevřela okno pokoje ve druhém patře a z okna vyskočila. ${ }^{9}$ Děti usmrcené následně žalovaly poskytovatele sociálních služeb o náhradu nemajetkové újmy podle \ 2959 obč. zák.

\section{Protiprávnost}

Protiprávnost je prvním předpokladem odpovědnosti za újmu. Podle \2985 obč. zák. platí, že každý odpovidá za porušeni zákona, smlouvy nebo dobrých mraví. V posuzovaných (A a B) a obdobných př́padech je složité rozhodnout, zda došlo k porušení povinností stanovených přímo zákonem anebo jde o porušení tzv. obecné prevenční povinnosti

7 DOLEŽAL, Tomáš. In: MELZER, Filip. Občanský zákoník: velký komentár. 1. vyd., Praha: Leges, 2013, s. 533-536.

8 Rozsudek Nejvyšš́ho soudu ze dne 14. 11. 2002, sp. zn. 25 Cdo 253/2001.

9 Usnesení Nejvyššího soudu ze dne 25 Cdo 552/2014. 
zakotvené v \ 2900 obč. zák. Judikatura k původnímu \415 OZ 1964, která je použitelná i nyní, dospěla k logickému a správnému řešení, že aplikace prevenčni povinnosti prüchází $v$ úvahu tehdy, neexistuje-li konkrétni právni úprava vątahujici se na jednáni, jehož protiprávnost se posuzuje. ${ }^{10}$ Povinnosti zařízení však nejsou ani v konkrétních předpisech, např. v zákoně č. 108/20006 Sb., o sociálních službách, přesně specifikovány a musí být dovozeny z obecnějších zásad, na kterých jsou příslušné předpisy postaveny. Není např. nikde specifikováno, co se myslí rádným dohledem nad pacienty anebo v jakých intervalech mají probíhat kontroly pacientů. Pro určení protiprávnosti tak musí být nejprve zjištěno, zda neexistuje speciální úprava a pokud nikoli, mưže soud protiprávnost dovodit z porušení obecné prevenční povinnosti.

Rozsah prevenční povinnosti byl za účinnosti OZ 1964 kritizován z důvodu, že je př́liš široký, což vedlo $\mathrm{k}$ nepřiměřenému rozšiřování odpovědnosti; judikaturu musela tuto povinnost korigovat. Obecná prevenční povinnost zakotvená v \ 2900 obč. zák. je oproti předchozí úpravě užší. Podle důvodové zprávy přiliš široké vymezení \ 415 OZ 1964 vedlo $\mathrm{v}$ praxi $\mathrm{k}$ nepředvídatelným efektům a vnášelo do soukromých poměrů prvky nejistoty.

\section{$5 \quad$ Náležitý dohled}

Povinnosti zdravotních zařízení ani těch, které poskytují sociální služby, nejsou nikde přesně vymezeny. Pracovníci těchto zařrizení (ošetřující lékaři, zdravotní sestry) se např. dotazují, v jakém intervalu mají probíhat kontroly pacientů. V prvním řešeném př́padu (A) bylo posuzováno, zda je dostatečná kontrola pacientů jednou za 30 minut. $\mathrm{V}$ prvé řadě je nutné upozornit, že nelze poskytnou taxativní výčet povinností, včetně např. intenzity a frekvence dohledu. Judikaturu Ústavního i Nejvyššího soudu dovozuje, že dohled nad nezletilým neznamená vždy nepretržity a bezprostredni dobled „na každém kroku“, avšak v závislosti na konkrétnich okolnostech musi být vytvoreny takové podminky, aby si nezletilé

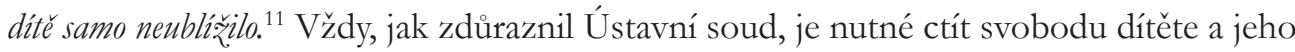
vývoj. ${ }^{12}$ 'Tyto závěry lze jednoznačně vztáhnout také na pacienty, nebot' takový postup odpovídá zásadě zohlednění individuálních potřeb osob, kterým jsou služby poskytovány a jež je zakotvena v \2 odst. 2 zákona o sociálních službách nebo v \3 odst. 3 zákona o zdravotních službách.

V rozhodnutí sp. zn. 25 Cdo 253/2011 Nejvyšší soud dovodil, že o zanedbání zvýšeného dohledu nad pacientem by bylo možné uvažovat tehdy, pokud byla pacientka bez dozoru pracovníků nemocnice po dobu delší než 30 minut. Tento závěr však nelze generalizovat, nebot' vždy musí být zohledněny individuální okolnosti prrípadu. V jiném

\footnotetext{
10 Usnesení Nejvyššího soudu ze dne 16. 5. 2002, sp. zn. 25 Cdo 1427/2001.

11 Rozsudek Nejvyššího soudu ze dne 25. 4. 2013, sp. zn. 25 Cdo 3298/2012.

12 Nález Ústavního soudu ze dne 13. 1. 2016 sp. zn. I. ÚS 1587/15.
} 
prrípadě pacient trpící akutní psychotickou poruchou a lehkou mentální retardací vyskočil z horního větracího okna ve společenské místnosti psychiatrické nemocnice. Soudy dospěly na základě provedeného dokazování k závěru, že všechny dveře byly zamčeny a všechna okna byla technicky jištěna proti otevření; pacient tak při vyskočení z okna musel překonat technické překážky, které byly dostačující, resp. dohled nad pacientem zanedbán nebyl. ${ }^{13}$

Ustanovení \110 odst. 4 zákona o sociálních službách upravuje odbornou způsobilost pracovníka; pracovníci musí mít náležité vzdělání a kurzy. Obdobně to platí pro pracovníky zdravotních služeb: poskytovatel je povinen poskytovat zdravotni služby na náležité odborné úrovni, vytvořit podminky a opatřeni k zajištèni uplatňováni práv a povinností pacienti a dalšich oprávnèných osob, zdravotnických pracovniku a jinyich odborných pracovnikü prĭ poskytováni zdravotnich služeb (』 45 odst. 1 qákona o zdravotních službách). Z těchto důvodů tak musí pracovníci rozpoznat, jakou péči pacient potřebuje, včetně intenzity dohledu, který nad ním má být vykonáván. Kvalifikovaný personál má být schopen určité míry předvídatelnosti. Podle německé judikatury musí být posouzeno, zda ošetřující lékař mohl předvídat určité jednání pacienta, resp. zda okolnosti nasvědčovaly tomu, že pacient by mohl např. spáchat sebevraždu. ${ }^{14}$

\section{Omezování pohybu}

Poskytovatelé sociálních služeb jsou podle $\int 88$ písm. c) povinni vytváret prí poskytováni sociálnich sluæ̌eb takové podminky, které umožni osobám, kterým poskytuji sociálni služby, naplňovat jejich lidská i občanská práva, a které zamezi stretim zájmů téchto osob se zájmy poskytovatele sociálni služby. K zásahu do osobnosti člověka (protiprávnost) může dojít v případě tzv. kurtování. Nejde o postup, který by byl protiprávní, nebot’ má své opodstatnění a nyní je upraven v př́mo v zákoně (\89 odst. 1 zákona o sociálních službách, \39 zákona o zdravotních službách). Platí, že pacienta lze omezit, avšak pouze tehdy, je-li účelem odvrácení bezprostředního ohrožení života, zdraví nebo bezpečnosti pacienta nebo jiných osob, a pouze na dobu, po kterou tyto důvody trvají. Obdobně může být pacient umístěn v sít’ovém lůžku. Opatření omezující pohyb tedy smí být použity jako prostředek ultima ratio a vždy s náležitým dohledem; pouhý neklid pacienta by neměl vést ke kurtování. Česká úprava a praxe byla kritizována také Evropským soudem pro lidská práva (dále jen „ESLP“). ESLP ve své judikatuře formuloval obecné zásady, které by měly být respektovány. Nejprve zdůraznil, že osoby postižené duševní poruchou, jsou velmi zranitelné a pokud je proti nim použita fyzická síla, která není nezbytně nutná, snižuje to lidskou důstojnost o to více; tím nevyloučil použití kurtů, avšak kontroly takto omezené osoby

13 Usnesení Nejvyššího soudu ze dne 16. 5. 2002, sp. zn. 25 Cdo 1427/2001.

14 BGH, Urteil vom 17. 2. 1982, Aktenzeichen 5 StR 520/81. 
musí probíhat pravidelně a délka trvání takového opatření nesmí být nepřiměřená. ${ }^{15}$ Je nesporné, že zavedené zásady mediciny jsou v takových prïpadech v zásadè roz̧odujici; obecně platí, že opatrené, které je z. leécebnébo blediska nutné, nelze považovat za nelidské nebo ponižnjici. Soud se však musi prèsvédčit, že lékařská nutnost byla proka a atelnè dokázána (Herczegfalyy proti Rakousku, rozsudek ze dne 24. zárí 1992, \82, Série A č. 244). Závěry rozsudku ESLP Bureš proti České republice lze vyložit takto: omezování osobní svobody za účelem snížení agresivity pacienta $\mathrm{v}$ zájmu ochrany ostatních pacientů nebo v zájmu ochrany před sebou samým je možné; takový postup však musí být náležitě odůvodněn, musí trvat pouze nezbytnou dobu a především musí být pacient pod náležitým dohledem. ${ }^{16}$

\section{Závěr}

Případy, ve kterých odpovídají zdravotní zařízení nebo zařízení, která poskytují sociální služby, jsou upraveny také v občanského zákoníku. Jde o zejména odpovědnost za škodu způsobenou vadou věci, odpovědnost za věci vnesené, odpovědnost za nezletilé osoby a za tzv. obecnou protiprávnost, zejména $\mathrm{v}$ prípadě zásahu do osobnostních práv (např. život, zdraví, důstojnost, soukromí apod.) pacientů a postup non lege artis. Při určení protiprávnosti jako prvního předpokladu odpovědnosti je vždy nejprve nutné dovodit porušení povinností v konkrétních předpisech a pokud zde povinnosti nejsou, až teprve je možné zvážit aplikaci tzv. generální prevenční povinnosti zakotvené v \2900 obč. zák. Tento postup však není snadný, protože povinnosti těchto zařízení jsou často stanoveny velmi obecně a nelze poskytnout jejich taxativní výčet. Vždy musí být vyváženy práva pacientů a pracovníků zařízení. Pracovníci by měli postupovat vždy s náležitou odbornou péčí a šetřit práva osob, kterým jsou služby poskytovány; jde o osoby velmi zranitelné. Typickým př́kladem vážení zájmů je právě náležitý dohled a svoboda pacienta.

15 Rozsudek ESLP ze dne 18. ř́jina 2012, Bureš proti ČR, č. stížnosti 37679/08.

16 Rozsudek ESLP ze dne 18. ŕíjna 2012, Bureš proti ČR, č. stížnosti 37679/08. 